\title{
Off-field transport of phosphorus from an Ultisol under pasture ${ }^{1,2}$
}

\author{
David Sotomayor-Ramírez, Gustavo A. Martínez, \\ Luis Pérez-Alegría ${ }^{5}$ and John Ramírez-Ávila ${ }^{6}$
}

J. Agric. Univ. P.R. 90(3-4):159-172 (2006)

\begin{abstract}
Broadcast applications of inorganic fertilizer and organic amendments to pastures can contribute significant phosphorus $(P)$ loads to surface waters. An experiment was conducted to quantify edge of field $P$ concentrations in runoff and mass losses from plots in an Ultisol-Oxisol complex amended with two inorganic $P$ levels [44 kg P/ha/yr (44PI) and $131 \mathrm{~kg} \mathrm{P/ha/yr}$ (131PI)], and an organic $P$ source (broiler litter) [131 kg P/ha/yr (131PO)]. The total amount of $\mathbf{P}$ was split in two applications for the organic treatment and in four for the inorganic treatments. Vegetation within plots was mainly naturalized tropical pastures ( $80 \%$ coverage) and the soil slope was between 10 and $12 \%$. Hydrologic discharge, suspended sediments, dissolved $P$ and total P (TP) were quantified over a one-year period to 7 August 2003. Runoff from each field was diverted to a fractionator, where 1 or $10 \%$ was collected. Of the 174 precipitation events, 59 resulted in significant runoff, and hydrologic discharge accounted for $22 \%$ to $35 \%$ of the total rainfall $(164.3 \mathrm{~cm})$. Sediment losses ranged from 230 to $818 \mathrm{~kg} / \mathrm{ha}$. Cumulative TP mass losses were 3.19, 7.04, and 5.02 kg P/ha, for the 44PI, 131PI, and 131PO treatments, respectively. These losses corresponded to $7.3,4.9$, and $3.5 \%$ of the annual $P$ applied in the treatments $44 \mathrm{PI}, 131 \mathrm{PI}$, and $131 \mathrm{PO}$, respectively. Although the magnitude of $P$ losses was relatively low from an agricultural production standpoint, these can impact surface-water quality via nutrient enrichment. The greatest magnitude of TP mass losses occurred when application coincided with frequent intense rainfall events.
\end{abstract}

Key words: phosphorus mass losses, broiler litter in pastures, phosphorus concentrations in runoff

${ }^{1}$ Manuscript submitted to Editorial Board 9 August 2005.

${ }^{2}$ Funding for this study was provided in part by a USDA-TSTAR grant. We appreciate the assistance of E. Ayala, V. Santiago, J. Aponte in the field; J. L. Guzmán and O. Santana in the laboratory; USDA-NRCS-Caribbean Area Personnel; and Dr. R. Macchiavelli in the statistical analyses.

${ }^{3}$ Professor, Agronomy and Soils Dept., College of Agricultural Sciences, Univ. of Puerto Rico-Mayagüez Campus, P.O. Box 9030, Mayagüez, PR 00681-9030.

${ }^{4}$ Professor, Agronomy and Soils Dept., College of Agricultural Sciences, Agric. Experiment Station, Rio Piedras.

${ }^{5}$ Professor, Agricultural Engineering and Biosystems Department, College of Agricultural Sciences, Univ. of Puerto Rico-Mayagüez Campus.

${ }^{6}$ Former graduate student, Agronomy and Soils Dept., College of Agricultural Sciences, Univ. of Puerto Rico-Mayagüez Campus. 


\title{
RESUMEN
}

\section{Transporte de fósforo en un Ultisol bajo pastura}

\begin{abstract}
Las aplicaciones de fertilizantes y enmiendas orgánicas a los suelos pueden contribuir cantidades significativas de fósforo $(P)$ a las aguas superficiales. Se realizó un experimento para cuantificar las concentraciones de $\mathbf{P}$ en la escorrentía y las pérdidas en masa de $\mathrm{P}$ al borde de predio en un Ultisol enmendado con dos niveles de superfosfato triple como fuente inorgánica de $\mathrm{P}$ [44 kg P/ha/año (44 PI) y $131 \mathrm{~kg} \mathrm{P/ha/año} \mathrm{(131PI)]} \mathrm{y} \mathrm{una} \mathrm{fuente} \mathrm{orgánica}$ de $P$ [131 kg P/ha/año (131PO)] aplicado como pollinaza. La aplicación de $P$ se fraccionó en dos para la fuente orgánica y en cuatro para la fuente inorgánica. La vegetación dentro de los predios era principalmente de pasturas tropicales naturalizadas y la pendiente varió entre 10 y $12 \%$. La descarga hidrológica, sedimentos suspendidos, $\mathrm{P}$ disuelto y $\mathrm{P}$ total se cuantificaron durante un año. La escorrentía de cada parcela se canalizó hacia un fraccionador donde se recolectó el $1 \% \circ$ el $10 \%$ de la misma. De los 174 eventos de precipitación, 59 resultaron en escorrentía significativa, y la descarga hidrológica varió entre 22 y $35 \%$ de la totalidad $(164.3 \mathrm{~cm})$. Las pérdidas de sedimento variaron entre 230 y $818 \mathrm{~kg} / \mathrm{ha} / \mathrm{año}$. Las pérdidas de $\mathrm{P}$ cumulativas fueron $3.19,7.04$, y $5.02 \mathrm{~kg}$ P/ha, para los tratamientos 44PI, 131PI, y $131 \mathrm{PO}$, respectivamente. Desde una perspectiva de producción agrícola, la magnitud de las pérdidas de $\mathrm{P}$ fueron bajas, pero estas cantidades pueden afectar las aguas superficiales vía el enriquecimiento nutricional. Las mayores pérdidas de $\mathbf{P}$ ocurrieron en periodos de tiempo cuando la aplicación coincidió con eventos de lluvia de relativamente alta intensidad y frecuencia.
\end{abstract}

Palabras clave: pérdidas de fósforo, pollinaza en escorrentía, concentraciones de fósforo en escorrentía

\section{INTRODUCTION}

Broiler and egg production in Puerto Rico accounts for over $15 \%$ of the gross agricultural income with a farm value of over $\$ 106$ million (Puerto Rico Department of Agriculture, 2002). There is an annual standing stock of approximately 41 million broiler hens and 20 million poultry hens in Puerto Rico that generates $187 \times 10^{6} \mathrm{~kg}$ manure (fresh) per year (Frederique-Alexandre, 2001). These amounts are equivalent to a nutrient production of about $2.57 \times 10^{6} \mathrm{~kg} \mathrm{~N}$ and $8.96 \times 10^{5} \mathrm{~kg} \mathrm{P} / \mathrm{yr}$. The broiler litter is usually spread on pasture fields and cash crops, and its application to small land areas that are characterized by a steep topography and sudden intense rainfall has generated concern in regard to its potential impact on surface water quality.

Nutrients, especially P, can be transported in runoff in dissolved or particulate form. In agricultural areas with large erosion losses such as those from plowed fields and bare soils, and where organic material is broadcast applied, a greater portion of the total nutrient losses is in particulate form (McDowell and Sharpley, 2001). This is accentuated when intense rainfall occurs following application, especially if the material has not been mineralized by soil microorganisms and if nutrients have not been incorporated within the soil matrix. Nutrient losses in dissolved form occur as a result of dissolution-desorption reactions following rainfall. 
A survey of broiler farms where broiler litter was applied showed that $37 \%$ of the plots evaluated had soil test $P$ values in excess of what is considered adequate for agricultural purposes (Martínez et al., 2002). Current loading rates for manure are guided by USDA-NRCS recommendations based on $\mathrm{N}$ extraction by crops, and are regulated by the Puerto Rico Environmental Quality Board. Current regulations recommend the application of a "thin-uniform layer over the vegetation" (PREQB, 2004). At typical manure loading rates of $11,170 \mathrm{~kg} / \mathrm{ha}$ (10,000 lb/acre) and P concentration of $1.2 \%$, this amounts to an annual loading rate of $134 \mathrm{~kg} \mathrm{P} / \mathrm{ha}$. The fertilizer recommendations for intensive pasture production in soils of Puerto Rico is $300 \mathrm{~kg} \mathrm{~N} / \mathrm{ha}$ and $44 \mathrm{~kg}$ P/ha (Vicente-Chandler et al., 1983).

Various studies have documented the effects of manure application on surface runoff-water quality in temperate areas by using simulated rainfall under field conditions (Edwards and Daniel, 1993; Pote et al., 1996; Ebeling et al., 2002), yet fewer studies have documented nutrient concentrations and losses after broiler litter and inorganic P application in soils under natural rainfall conditions (Nichols et al., 1994; Kimmel et al., 2001). Variation of P concentrations and mass losses for potential contributions to nonpoint-source pollution need to be evaluated in relation to diverse site and soil characteristics. Phosphorus runoff patterns in areas of the humid tropics may contrast from those in temperate areas because of high temperatures favoring increased organic residue decomposition, more intense and frequent rainfall events, and higher P-fixing capacity of highly weathered soils. The objectives of this study were to quantify runoff concentrations and mass losses of suspended sediments (TSS), total P (TP) and dissolved reactive $\mathrm{P}$ (DP) from an Ultisol-Oxisol complex under pasture production amended with two sources of $P$.

\section{MATERIALS AND METHODS}

The experiment was conducted within a 2.5-ha field on Finca Alzamora (University Farm) in Mayagüez, Puerto Rico. The soil at the site is an Ultisol-Oxisol complex consisting of greater portions of Humatas (very-fine, parasequic, isohyperthermic Typic Haplohumults) and Consumo (fine, mixed, semiactive, isohyperthermic Typic Haplohumults) series, and lesser portions of Dagüey (very-fine, kaolinitic isohyperthermic Inceptic Hapludox) series (Beinroth et al., 2003). Onsite soil series confirmation was performed with collaboration of USDA-NRCS-Caribbean Area personnel. Plant species composition at the site was naturalized pastures which primarily included major extents of Bahia (Paspalum notatum), Bermuda (Cynodon dactylon), 
Grama Colorada (Axonopus compressus), and Cerrillo (Sporobolus indicus), with minor components of Gramalotillo (Paspalum plicatulum) and Horquetilla (Paspalum conjugatum) (CNWG, 2004). Soil slope ranged from 10 to $12 \%$. The fields had not been fertilized for at least two years prior to experiment initiation. Initial plant percentage cover ranged from 75 to $85 \%$ for all plots.

Two groups (blocks) of three plots were established within the 2.5ha field. The plots were approximately $28 \mathrm{~m}^{2}(9 \mathrm{~m}$ downslope $\times 3.1 \mathrm{~m}$ across), and were surrounded by $15-\mathrm{cm}$ polyethylene liners inserted 6 $\mathrm{cm}$ into the soil to exclude run-on water and to direct runoff water to runoff fractionators/collectors (runoff collectors) placed at the drainage point of each plot.

Runoff collectors were those described by Franklin et al. (2001) in which one-tenth (10x) or one-hundredth (100x) of total runoff was collected. Polyethylene tubing connected the runoff collector to the holding tanks, which were polyethylene buckets located downslope from the runoff fractionator with the top inserted approximately $5 \mathrm{~cm}$ below the soil surface. The buckets had lids to prevent rainfall from entering. Runoff was collected from the buckets within $24 \mathrm{~h}$ of each runoff event. Total volumes corresponding to each fraction were recorded. Collectors, tubing and buckets were rinsed with acid-solution and distilled water between events.

Runoff water collected in the buckets was vigorously stirred and a portion was added to $500-\mathrm{mL}$ Whirl-Pak ${ }^{\circledR 7}$ polyethylene sterile bags. Samples were transported to the laboratory and immediately frozen until processing. Total suspended solids (hereafter referred to as suspended sediments) were filtered through a glass fiber filter (Whatman GF/F) (EPA method 160.1) (USEPA, 1999). The unfiltered subsample was digested by using the acidic persulfate oxidation method (Pote and Daniel, 2000). Orthophosphate-P in digest and filtered water was quantified by using the ascorbic acid method (Murphy and Riley, 1962), followed by quantification using a Bran+Luebbe Autoanalyzer. Instrument specifications, reagent make-up, and additional details are outlined in Bran+Lubbe AutoAnalyzer Applications (Method no. 696A$82 \mathrm{~W})$. Particulate $\mathrm{P}$ was defined as the difference between TP and DP forms, assuming that the majority of the total $\mathrm{P}$ in the filtered portion is in dissolved form (Pierzinsky and Sharpley, 2000).

\footnotetext{
TTrade names in this publication are used only to provide specific information. Mention of a trade name does not constitute a warranty of equipment or materials by the $\mathrm{Ag}$ ricultural Experiment Station of the University of Puerto Rico, nor is this mention a statement of preference over other equipment or materials.
} 
Verification of runoff fractionator functioning was performed by applying water at a rate of $8 \mathrm{~L} / \mathrm{min}$ to an area of approximately $0.28 \mathrm{~m}^{2}$ during a 10-min time period. The proportion of water collected in relation to the amount of water added ranged from 40 to $96 \%$. As expected, the proportion of water added and collected as runoff increased when the three trials were performed consecutively on the same day. The runoff ratio between the $10 \times$ and $100 \times$ holding tanks for all the fractionators was $8.4 \pm 1.6$ (mean \pm 1 standard deviation). The same trend was observed for empirical data collected during the experiment (June through December 2002).

Three treatments ( $\mathrm{P}$ applications) were randomly applied to plots within each block. The treatments consisted of a low inorganic $P$ level of $44 \mathrm{~kg} \mathrm{P} / \mathrm{ha}$ (44 PI), a high inorganic P level of $131 \mathrm{~kg} \mathrm{P} / \mathrm{ha}$ (131 PI), and a high organic $\mathrm{P}$ level of $131 \mathrm{~kg} \mathrm{P} / \mathrm{ha}$ (131 PO). The P source for the low inorganic $\mathrm{P}$ level and for $1 / 3$ of the high inorganic $\mathrm{P}$ level was diammonium phosphate. The remaining $2 / 3$ of the $\mathrm{P}$ source for the high inorganic $\mathrm{P}$ level was triple superphosphate. Both inorganic $\mathrm{P}$ treatments received $300 \mathrm{~kg} \mathrm{~N} / \mathrm{ha}$ (the remaining $\mathrm{N}$ needed was supplemented with urea) and $167 \mathrm{~kg} \mathrm{~K} / \mathrm{ha} / \mathrm{yr}$ as $\mathrm{KCl}$. The organic $\mathrm{P}$ source was broiler litter, and the amount applied was based on the manure total $\mathrm{P}$ concentration. Organic and inorganic $P$ levels and selected timing were typical of those applied on agricultural farms of Puerto Rico. The organic $P$ was applied at six-month intervals (7 August 2002, 8 February 2003, and 8 August 2003); whereas the inorganic P treatments were applied at three-month intervals (7 August 2002, 7 November 2002, 8 February 2003, 8 May 2003, and 8 August 2003).

Precipitation amounts and intensity (10-min intervals) were obtained from the Caribbean Atmospheric Research Center (ATMOS) in Mayagüez, located approximately $3 \mathrm{~km}$ from the study site, from 5 June to 15 November 2002. From 15 November 2002, a tipping bucket rain collector with a data logger was placed on site and precipitation intensity and duration were recorded.

Pasture was uniformly mown on 17 July 2002, and harvested on 6 September 2002, 2 November 2002, 7 February 2003, 7 May 2003, and 7 August 2003. Plant moisture, fresh and dry weights were recorded. The soils $(0$ to $5 \mathrm{~cm}$ ) within plots were sampled in August 2002 and August 2003 and analyzed for extractable $\mathrm{P}$ by the Olsen-bicarbonate and Bray 1 methods.

The $\log 10$ transformation of TP, DP and suspended sediment concentrations and cumulative values of TSS, TP and DP were subjected to analysis of variance using SAS (SAS Institute, 2001). Treatment comparisons and the effect of time of the year were also performed by grouping data collected during the distinct wet season of 1 August to 31 
November and that which occurred during the rest of the year (December 2002 to July 2003). Within treatment comparisons were performed to examine the effect of proximity to fertilization and organic amendment by grouping runoff data which occurred 10 days after fertilization and organic amendment and comparing those results with data collected on all other dates. The data are presented as the antilog values of least squares means when $\log 10$ transformed data were used.

\section{RESULTS AND DISCUSSION}

\section{Hydrology}

Mean daily precipitation had a bimodal distribution with greatest precipitation depths and occurrence between August and November 2002 and lesser depths and occurrence during April, May and July 2003 (Figure 1). There were 174 precipitation events with a cumulative annual total of $164.3 \mathrm{~cm}$. At least $50 \%$ of the precipitation occurred in 73 events having rainfall depths between 1 and $3 \mathrm{~cm}$, and durations between 30 and 60 minutes. Rainfall events with depths greater than 3 $\mathrm{cm}$ (10 events) contributed to $30 \%$ of the total rainfall and had a mean duration of $2.1 \mathrm{~h}$. These events occurred on the following dates: $10 \mathrm{Au}-$ gust 2002, 26 August 2002, 19 September 2002, 20 October 2002, 5 November 2002, 4 April 2003, 14 April 2003, 9 May 2003, 6 June 2003, and 5 July 2003 . Of these ten events, those occurring during $2002 \mathrm{had}$ mean five-day antecedent precipitations of $2.54 \mathrm{~cm}$, and mean runoff values ranging from 1.91 to $4.28 \mathrm{~cm}$. In contrast, runoff events occurring during 2003 had mean five-day antecedent precipitations of $1.0 \mathrm{~cm}$ and mean runoff values ranging between 0.01 to $0.15 \mathrm{~cm}$. The increase in pasture growth seen by May 2003 suggests that at this point the grasses were receiving enough nutrients, in contrast to pre-experimental record of nutrient availability since the plots did not have a historical record of fertilization or manure addition (Table 1). The precipitation events where greater runoff occurred were related to greater precipitation depths, higher soil moisture levels prior to the events, and lower plant growth, in contrast to those events occurring during 2003.

Cumulative runoff was $22.5,37.5$, and $40.2 \mathrm{~cm}$ for the 44 PI, $131 \mathrm{PO}$, and 131 PI treatments, respectively, with no significant difference among them $(P>0.1)$. Sediment yields did not differ among treatments, and cumulative annual losses ranged from 230 to $818 \mathrm{~kg} / \mathrm{ha}$. These values are in accordance with measured sediment losses from grassland sites in Puerto Rico (Lugo-López et al., 1981). Overall, there were 59 runoff events for a mean total runoff depth of $33.4 \mathrm{~cm}$, with $57 \%$ of the events occurring between 6 August and 30 November 2002 (Figure 1). In spite of the fact that there were 32 runoff events between 


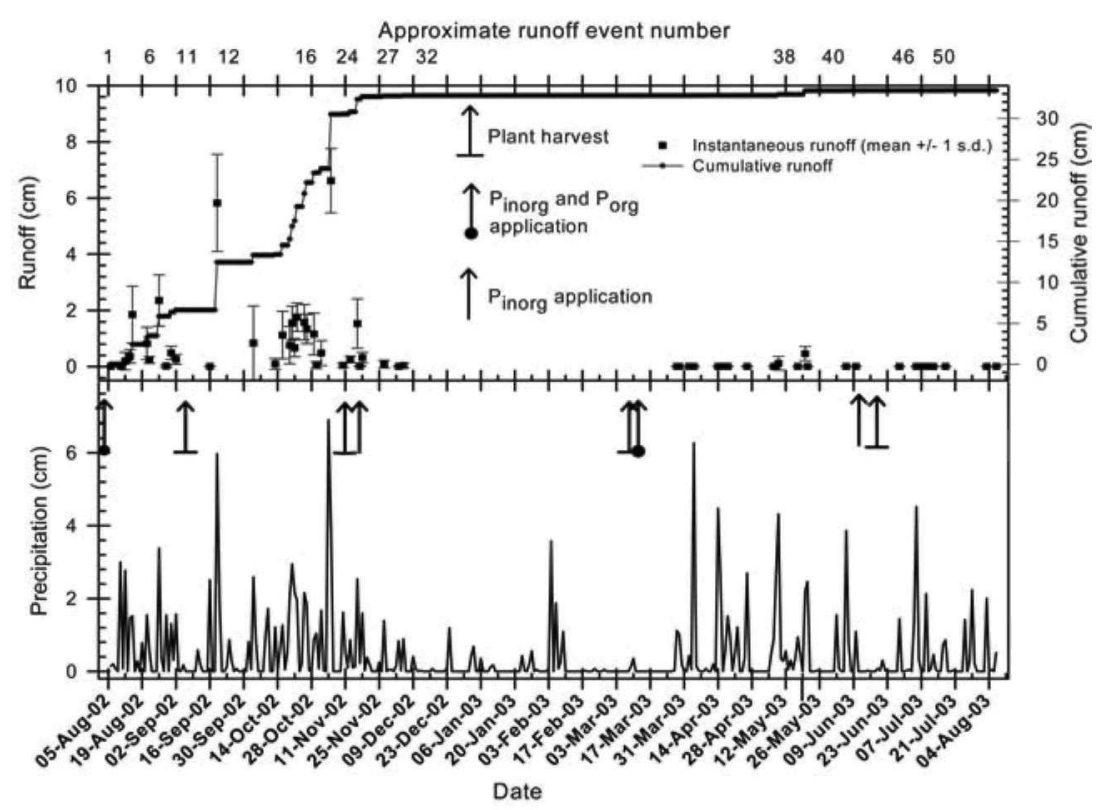

FIGURE 1. Mean daily precipitation, runoff and cumulative runoff occurring at Finca Alzamora from August 2002 to August 2003. The top portion of the abseissa represents runoff event number which corresponds to a particular date.

August and 31 November 2002, and 27 runoff events between 1 December 2002 and 7 August 2003, the majority of runoff depth (97\%) occurred within the former time period (mean runoff depth of $32.7 \mathrm{~cm}$ ). On days when runoff occurred, the proportion of days with rainfall durations greater than $30 \mathrm{~min}(88 \%$ and $93 \%)$ and intensities greater than $1 \mathrm{~cm}(63$ and $66 \%$ ) was similar for the two periods.

\section{Total $P$ and DP Concentrations}

Mean TP concentrations in runoff were $1.32,1.48$ and $1.97 \mathrm{mg} \mathrm{P} / \mathrm{L}$ for 44 PI, 131 PI, and 131 PO treatments, respectively. Mean DP concentrations in runoff were $0.988,1.12$, and $1.91 \mathrm{mg} \mathrm{P} / \mathrm{L}$ for $44 \mathrm{PI}, 131 \mathrm{PI}$, and $131 \mathrm{PO}$ treatments, respectively. The $131 \mathrm{PO}$ treatment was significantly greater than the other two treatments for $\mathrm{TP}(\mathrm{P}<0.1)$ and for DP $(\mathrm{P}<0.01)$. Mean TP and DP concentrations were highly influenced by runoff event 29 (16 November 2002), which occurred nine days after fertilization with inorganic $\mathrm{P}$, and where concentrations in runoff of 14.2 and $22.3 \mathrm{mg}$ P/L were measured for 44PI and 131PI treatments, respectively (Figure 2 ). 
TABLE 1. Soil test $P$ data and plant dry matter yields during the experiment.

\begin{tabular}{|c|c|c|c|c|c|c|c|}
\hline \multirow[b]{2}{*}{ Treatment } & \multirow[b]{2}{*}{$\begin{array}{l}\text { Soil test } P \\
(\text { Bray1) }\end{array}$} & \multicolumn{6}{|c|}{ Plant dry matter yield } \\
\hline & & $\begin{array}{l}\text { Sept. } \\
2002\end{array}$ & $\begin{array}{l}\text { Nov. } \\
2002\end{array}$ & $\begin{array}{l}\text { Feb. } \\
2003\end{array}$ & $\begin{array}{l}\text { May } \\
2003\end{array}$ & $\begin{array}{l}\text { Aug. } \\
2003\end{array}$ & $\begin{array}{c}\text { Annual } \\
\text { total }^{2}\end{array}$ \\
\hline & $\mathrm{mg} \mathrm{P} / \mathrm{kg}$ & $-\ldots$ & - . . - & 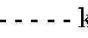 & a $\ldots . .$. & $-\ldots$. & $-\ldots . . .-$. \\
\hline 44 PI & 16.4 & 2,087 & 1,667 & 743 & 10,775 & 5,104 & 20,377 \\
\hline 131 PI & 53.6 & 1,864 & 1,585 & 687 & 11,795 & 6,033 & 23,021 \\
\hline $131 \mathrm{PO}$ & 120.7 & 2,088 & 1,667 & 743 & 10,775 & 3,787 & 17,018 \\
\hline
\end{tabular}

${ }^{1}$ Data from August 2003, at the end of the experiment.

${ }^{2}$ Annual total includes the sum of September 2002 through August 2003.

Runoff TP and DP concentrations were lower from August to November 2002 than those from December 2002 to July 2003 (effect of season), with mean TP and DP concentrations of 1.33 and $1.17 \mathrm{mg}$ P/L, respectively, in the former and 3.01 and $2.47 \mathrm{mg} \mathrm{P} / \mathrm{L}$, respectively, in the latter. Although there was a series of rainfall events during April, May and July, there was vigorous plant growth as a result of previous fertilization and manure application and increased day length which did not reduce $\mathrm{TP}$ concentrations as expected. The dissolved portion of $\mathrm{P}(\mathrm{DP})$ is a fraction of the total $\mathrm{P}$ present in runoff and is the $\mathrm{P}$ form immediately available for uptake by biota in the water column, in contrast to particulate $\mathrm{P}$, which can provide a long-term $\mathrm{P}$ source for aquatic plant growth (Sharpley et al., 1995). Suspended sediment concentrations were lower from December 2002 to July 2003 than from August to November 2002, and these were not high enough apparently to favor $\mathrm{P}$ re-adsorption to soil particles, all of which reduces the dissolved P fraction (Gillingham and Thorrold, 2000; Mullins and Hajek, 1997). Similar proportions of

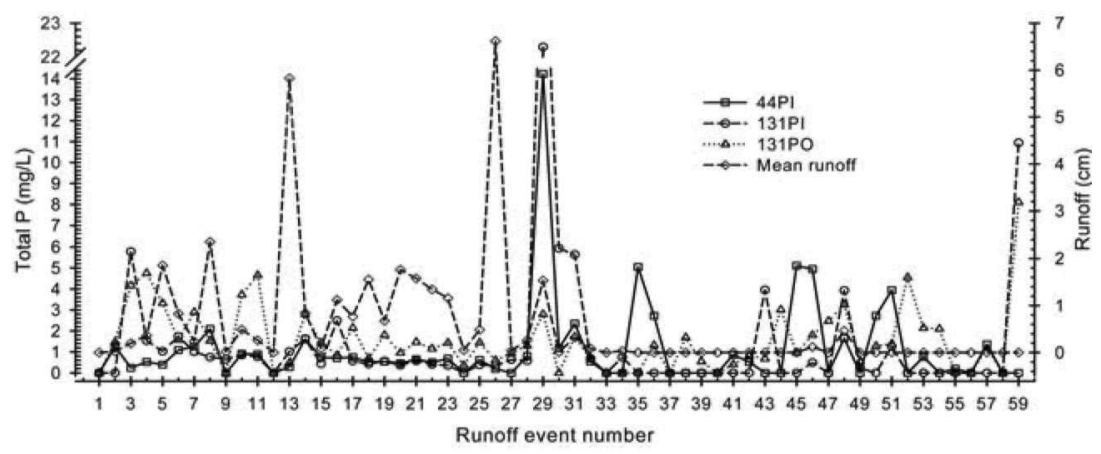

FIGURE 2. Total $P$ concentrations in runoff at Finca Alzamora from August 2002 to August 2003. Runoff events correspond to dates described in Figure 1. 
the total $\mathrm{P}$ were in dissolved form for the two periods (mean value of $85 \%$ ), yet particulate $\mathrm{P}$ was highest in the time period from December 2002 to July 2003 . This finding suggests that a large portion of $P$ transported in runoff may be due to fertilizer and/or organic material that did not contact soil when applied, possibly because of plant canopy interaction or soil moisture conditions that were not conducive for mineralization and solubilization (Gillingham and Thorrold, 2000). High P concentrations need not necessarily relate to high P losses due to low runoff volume losses and $\mathrm{P}$ dilution following soil desorption or fertilizer/manure solubilization from the rainfall/runoff event.

The TP and DP concentrations were higher $(\mathrm{P}<0.05)$ in runoff within 10 days after fertilization or organic amendment than in runoff events occurring more than 10 days after fertilization. Edwards et al. (1996) observed that runoff during storms which occurred soon after fertilizer application usually had much higher TP concentrations than runoff during storms preceding fertilizer application. An exception to this occurred for the February application (between events 32 and 38), because of the low amount of rainfall two months prior to and almost one month following the application date, all of which resulted in very low runoff. The effect of application date on runoff nutrient concentrations is further illustrated by what occurred in event 26 (prior to inorganic $P$ fertilization) and event 29 (after inorganic P fertilization). In event 29 on 16 November 2002 , there was a $90-\min 2.54-\mathrm{cm}$ rainfall event with a mean runoff depth of $1.53 \mathrm{~cm}$, which was preceded by six consecutive days of rainfall. Mean TP concentrations were nearly seventy times greater than those observed in runoff event 26 on 5 November 2002 (mean TP concentrations of $0.265 \mathrm{mg} / \mathrm{L}$ ), which corresponded to an 80min 4.04-cm rainfall event with a mean runoff depth of $6.6 \mathrm{~cm}$.

The skewness coefficients for the log-transformed data of TP and DP concentrations were slightly improved for the inorganic treatments and did not change for the organic treatment after removal of event 29, despite the fact that $\mathrm{P}$ was applied in greater amounts for the organic treatment (the organic treatment was split-applied in two and the inorganic treatment was split-applied in four). The data suggest that inorganic $\mathrm{P}$ may be as susceptible to $\mathrm{P}$ losses, at equal rates of $\mathrm{P}$ applied as organic $P$, because of the initial higher solubility and $P$ availability in TSP as compared to that of the organic manure.

\section{Total P and DP Edge of Field Mass Losses}

Mean TP mass losses were 39.4, 81.1, and 74.2 g P/ha, and mean DP mass losses were $34.7,74.8$, and $76.5 \mathrm{~g} \mathrm{P} /$ ha for $44 \mathrm{PI}, 131 \mathrm{PI}$, and 131 PO treatments, respectively (Figure 3). Edwards et al. (1996) reported 


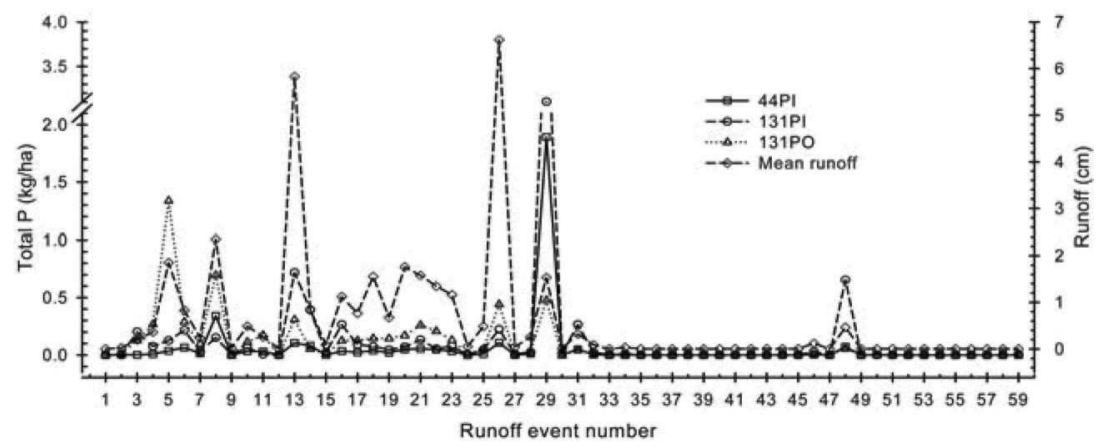

FIGURE 3. Total P mass losses at Finca Alzamora from August 2002 to August 2003. Runoff events correspond to dates described in Figure 1.

event-based mean runoff TP losses ranging from 80 to $260 \mathrm{~g}$ P/ha in fields amended with poultry manure or poultry litter at annual rates ranging from 119 to $209 \mathrm{~kg}$ P/ha. Inorganic fertilizer P was applied two days after event 26 , three days prior to event 27 , and nine days prior to event 29, the latter of which resulted in the highest TP concentrations. Precipitation depth and intensity was $30 \%$ lower in event 27 than in event 29, and runoff depths averaged 0.040 and $1.53 \mathrm{~cm}$ for $44 \mathrm{PI}$ and 131 PI, respectively. Mean TP and DP mass losses were reduced on average $34 \%$ when event 29 was not included, and did not change when event 27 was excluded. In both instances, low plant height favored lower canopy precipitation interception, with concomitant lower infiltration than would have been observed with greater plant stand. Because precipitation intensity and depths were lower in event 27 than in event 29, lower P concentrations, lower runoff and lower mass losses were observed. Thus, not only is the time after application an important variable to consider with regard to $\mathrm{P}$ losses, but also precedentand event-based rainfall depth and intensity.

Overall, cumulative annual TP mass losses were $3.19,7.04$, and $5.02 \mathrm{~kg} / \mathrm{ha}$ for the $44 \mathrm{PI}, 131 \mathrm{PI}$, and 131 PO treatments, respectively (Figure 4). Our values with the 44PI treatment were within reported ranges, yet for $131 \mathrm{PI}$ and $131 \mathrm{PO}$ treatments values were greater than those reported by Edwards et al. (1996), which ranged from 1.6 to 4.3 $\mathrm{kg} / \mathrm{ha}$. Our DP concentrations and mass losses were 10 times greater than those measured by Ebeling et al. (2002), where $108 \mathrm{~kg} \mathrm{P} / \mathrm{ha}$ as dairy manure $\mathrm{P}$ was applied to a Mollisol under pasture in Wisconsin during 18 precipitation events ranging from 0.3 to $16.9 \mathrm{~cm}$. Measured $P$ losses from pastureland in New Zealand and in Georgia, USA, 
ranged from 0.1 to $1.67 \mathrm{~kg} \mathrm{P} / \mathrm{ha} / \mathrm{yr}$ (Gillingham and Thorrold, 2000; Kuykendall et al., 1999).

Very low TP losses occurred from December to August 2003, whereas TP losses from August to November (events 1 to 32 ) were 97\%, $90 \%$, and $98 \%$ of cumulative annual losses for the 44 PI, 131 PI, and 131 PO treatments, respectively. Increased grass growth after February 2003 greatly reduced runoff and hence TP and DP mass losses. Overall, TP mass losses were primarily driven by runoff volume. Thus, in spite of the fact that TP concentrations were higher from December 2002 to July 2003, total losses during this period were lower. As occurred with TP concentrations, TP and DP cumulative mass losses were always greater $(\mathrm{P}<0.05)$ when runoff occurred within 10 days after fertilization or organic amendment.

From runoff events 5 to 28 , the highest cumulative TP loss was observed for the 131PO as compared to that of the inorganic treatments (Figure 4). After the second inorganic $\mathrm{P}$ application, which occurred on 7 November 2002 (prior to event 27), TP concentrations in event 29 significantly increased for the 131 PI treatment over those of the $131 \mathrm{PO}$ treatment. The stepwise increase was also observed for the 44 PI, yet mass losses were lower than in the other treatments. Increased P mass losses from the inorganic P-amended treatments occurred when high TP concentrations in soil solution coincided with high soil moisture conditions, high precipitation depth and intensity, and low grass stand, conditions which were conducive for increased runoff. The high P concentrations in runoff during events 42 to 59 did not cause high $\mathrm{P}$ losses from the plots because of low runoff from plots.

Greater TP concentrations and mass losses have been observed with increases in soil test $\mathrm{P}$ values (Sharpley, 1995; Pote et al., 1996; McDow-

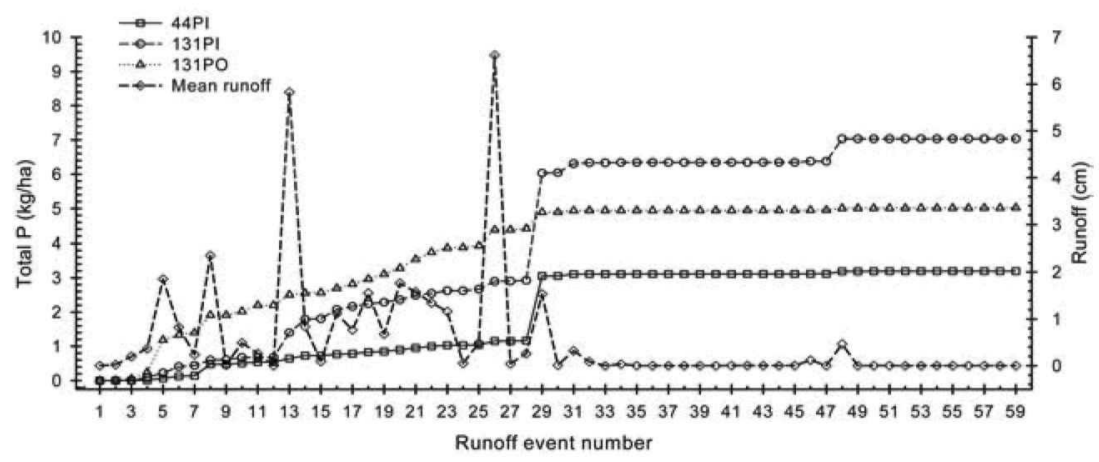

FIGURE 4. Cumulative total P mass losses at Finca Alzamora from August 2002 to August 2003. Runoff events correspond to dates described in Figure 1. 
ell and Sharpley, 2001; Ramírez, 2005). The mass loss patterns observed with regard to the treatments do not necessarily relate to the soil test $P$ values measured at the end of the experiment (Table 1). This probably occurred in this experiment because a large number of TP concentration and mass losses within newly applied inorganic or organic material were from newly solubilized $P$ within the fertilizer- or manure-soil-solution interface, and not from $\mathrm{P}$ in solution and fixed $\mathrm{P}$, which is measured by a soil test (Pautler and Sims, 2000; Bowman and Vigil, 2003).

\section{CONCLUSIONS}

Concentrations of TP and DP in runoff and mass losses were measured in response to $\mathrm{P}$ application regimes and precipitation events during a one-year period. The application of organic $\mathrm{P}$ resulted in greater TP and DP concentrations than the same amount of $\mathrm{P}$ added in inorganic form but not in greater P mass losses. Greater TP concentrations were observed during the drier season from December 2002 to July 2003 but $P$ mass losses were significantly lower. Hydrology in the form of runoff volumes was the principal variable influencing TP and DP mass losses. Increased nutrient additions resulted in enhanced grass growth during the months of December 2002 to June 2003, all of which reduced runoff volumes but increased runoff $\mathrm{P}$ concentrations. Runoff events occurring within 10 days after fertilization or organic amendment resulted in TP and DP concentrations and mass losses greater than those of the other dates. The degree to which nutrient application contributes to runoff $P$ losses declines with the increase in the time before runoff occurrence as well as with increased plant biomass and height. These results provide quantitative evidence to guide $\mathrm{P}$ management in tropical agricultural systems.

\section{LITERATURE CITED}

Beinroth, F. H., R. J. Engel, J. L. Lugo, C. L. Santiago, S. Ríos and G. R. Brannon, 2003. Updated taxonomic classification of the soils of Puerto Rico. Bulletin no. 303. University of Puerto Rico, Agricultural Experiment Station, College of Agricultural Sciences. San Juan, PR. 73 pp.

Bowman, R.D. and M.F. Vigil, 2003. Soil testing and analysis for different phosphorus pools. J. Soil Water Cons. Soc.

Catalogue of New World Grasses (CNWG), 2004. R. J. Soreng et al. (ed.). Revised November 2004. Available at: http://mobot.mobot.org/W3T/Search/nwge.html. Verified on 7 February 2005.

Department of Agriculture, Puerto Rico, 2002. Ingreso Bruto Agrícola. Department of Agriculture, Commonwealth of Puerto Rico. $16 \mathrm{pp}$.

Ebeling, A. M., L. G. Bundy, J. M. Powell and T. W. Andraski, 2002. Dairy diet phosphorus effects on phosphorus losses in runoff from land-applied manure. Soil Sci. Soc. Am. J. 66:284-291. 
Edwards, D. R. and T. C. Daniel, 1993. Effects of poultry litter application rate and rainfall intensity on quality of runoff from Fescuegrass plots. J. Environ. Qual. 22:361-365.

Edwards, D. R. T. C. Daniel, J. F. Murdoch and P. A. Moore, Jr., 1996. Quality of runoff from four northwest Arkansas pasture fields treated with organic and inorganic fertilizer. Trans. ASAE. 39:1689-1696.

Franklin, D. H., M. L. Cabrera, J. L. Steiner, D. M. Endale and W. P. Miller, 2001. Evaluation of percent flow captured by a small in-field runoff collector. Trans. ASAE. 44:551-554.

Frederique-Alexandre, E. A., 2001. Plan estratégico para el manejo de desperdicios de pollos y gallinas ponedoras. Propuesta de un proyecto de manejo sustentable de la gallinaza en Puerto Rico. Commonwealth of Puerto Rico, Puerto Rico Land Authority, Department of Agriculture. Santurce, P.R. 49 pp.

Gillingham, A. G. and B. S. Thorrold, 2000. A review of New Zealand research measuring phosphorus in runoff from pasture. J. Environ. Qual. 29:88-96.

Kimmel, R. J., G. M. Pierzynski, K. A. Janssen and P. L. Barnes, 2001. Effects of tillage and phosphorus placement on phosphorus runoff losses in a Grain Sorghum-Soybean rotation. J. Environ. Qual. 30:1324-1330.

Kuykendall, H. A., M. L. Cabrera, C. S. Hoveland, M. A. McCann and L.T. West, 1999. Stocking method effects on nutrient runoff from pastures fertilized with broiler litter. J. Environ. Qual. 28:1886-1890.

Lugo-López, M. A., F. Abruña and R. Pérez-Escolar, 1981. The role of crop and industrial residues on erosion control, properties and productivity of some major soils of Puerto Rico. University of Puerto Rico, College of Agricultural Sciences, Agricultural Experiment Station. Bulletin 266. Río Piedras, Puerto Rico. 26 pp.

Martínez, G. A., D. Sotomayor-Ramírez and J. A. Castro, 2002. Application of the Caribbean $\mathrm{P}$ index to soils receiving organic amendments. J. Agric. Univ. P.R. 86:145-154.

McDowell, R. W. and A. N. Sharpley, 2001. Approximating phosphorus release from soils to surface runoff and subsurface drainage. J. Environ. Qual. 30:508-520.

Mullins, G. L. and B. F. Hajek, 1997. Phosphorus accumulation and loss from Alabama soils receiving poultry litter. Bulletin no. 631. Alabama Agric. Exp. Sta. 63 pp.

Murphy, J. and J. R. Riley, 1962. A modified single solution method for the determination of phosphate in natural waters. Anal. Chem. 27:31-36.

Nichols, D. J., T. C. Daniel and D. R. Edwards, 1994. Nutrient runoff from pasture after incorporation of poultry litter or inorganic fertilizer. Soil Sci. Soc. Am. J. 58:12241228.

Pautler, M. C. and J. T. Simms, 2000. Relationship between soil test phosphorus, soluble phosphorus and phosphorus saturation in Delaware soils. Soil Sci. Soc. Am. J. 64:765-773.

Pierzynski. G. M. and A. N. Sharpley, 2000. Methods of phosphorus analysis in soils, sediments, residuals, and waters: Introduction. In: G. M. Pierzynski (ed.) Methods of phosphorus analysis for soils, sediments, residuals and waters. Southern Cooperative Series Bulletin no. 396. Available at: http://www.soil.nesu.edu/sera17/publications/sera17-2/pm_cover.htm.

Pote, D. H. and T. C. Daniel, 2000. Analyzing for total phosphorus and total dissolved phosphorus in water samples. pp. 94-97. In: G. M. Pierzinsky (ed). Methods for phosphorus analysis for soils, sediments, residuals, and waters. Southern Cooperative Series Bulletin no. 396. URL: http://www.soil.nesu.edu/sera17/publications/ sera17-2/pm_cover.htm

Pote, D. H., T. C. Daniel, A. N. Sharpley, P. A. Moore, Jr., D. R. Edwards and D. J. Nichols, 1996. Relating extractable soil phosphorus to phosphorus losses in runoff. Soil Sci. Soc. Am. J. 60:855-859. 
PREQB (Puerto Rico Environmental Quality Board), 2004. Reglamento para el manejo de los residuos de empresas agrícolas. Commonwealth of Puerto Rico. Office of the Governor. 82 pages with appendix (in Spanish).

Ramírez, J. J., 2005. Transporte de sedimentos y fósforo en escorrentía bajo condiciones de simulación de lluvia. M.S. Thesis. Univ. of Puerto Rico, Mayagüez Campus. 164 pp.

SAS Institute, 2001. SAS User's Guide. Release 8.01. SAS Institute, Cary, NC.

Sharpley, A. N., 1995. Dependence of runoff phosphorus on extractable soil phosphorus. J. Environ. Qual. 24: 920-926.

Sharpley, A. N., M. J. Hedley, E. Sibbensen, A. Hillbricht-Illkowska, A. A. House and L. Ryszkowski, 1995. Phosphorus transfers from terrestrial to aquatic ecosystems. In: H. Tiessen. Scope 54-Phosphorus in the Global Environment-Transfers, Cycles, and Management. John Wiley and Sons, LTD. Online: http://www.icsuscope.org/index.htm. Verified on 15 April 2005.

USEPA, 1999. EPA Methods and guidance for analysis of water. USEPA, Wash. D.C. CD-ROM ver. 2.0 .

Vicente-Chandler, J., F. Abruña, R. Caro-Costa and S. Silva, 1983. Produeción y utilización intensiva de forrajeras en Puerto Rico. University of Puerto Rico, Agricultural Experiment Station, College of Agricultural Sciences. Bulletin 271. San Juan, PR. 226 pp. (in Spanish). 